\title{
Plasma Adipsin as a Biomarker and Its Implication in Type 2 Diabetes Mellitus
}

This article was published in the following Dove Press journal:

Diabetes, Metabolic Syndrome and Obesity: Targets and Therapy

\section{Gebrehiwot Gebremedhin \\ Tafere (1D) \\ Dawit Zewdu Wondafrash \\ Kaleab Alemayehu Zewdie (D) \\ Brhane Teklebrhan Assefa (D) \\ Muluken Altaye Ayza (D)}

Department of Pharmacology and Toxicology, School of Pharmacy, Mekelle University, Mekelle, Ethiopia
Correspondence: Gebrehiwot Gebremedhin Tafere Department of Pharmacology and Toxicology,School of Pharmacy, Mekelle University, P.O. Box: I87I, Mekelle, Ethiopia

Tel +25। 908822323

Email gebrehiwotg07@gmail.com

\begin{abstract}
Diabetes mellitus (DM) is a worldwide health threat affecting millions of people, which is associated with different micro- and macro-vascular complications. Type 2 diabetes mellitus (T2DM) is one of the different types of DM caused by insulin resistance and/or reduced secretion of insulin from the pancreas. A validated novel biomarker is required to enhance the accuracy of disease prediction, provide novel insights into pathophysiology and contribute to future prevention of T2DM. Various newer diagnostic methods have been developed by targeting endogenous proteins among which Adipsin is one of the promising target. Therefore, this review discusses Adipsin as a potential biomarker and its implication in T2DM. Adipsin is one of the adipokines secreted by adipose tissues which is involved in maintaining adipose tissue homeostasis and increasing insulin secretion in response to glucose. According to different experimental and clinical studies, plasma Adipsin concentrations are low in animals and patients with DM which support its use as a biomarker in combination to the other diagnostic modalities for DM. Additionally, the existence of Adipsin could be important in improving hyperglycemia by preserving $\beta$-cell mass through improving $\beta$-cell survival and maintaining their transcriptional identity.
\end{abstract}

Keywords: adipsin, type 2 diabetes mellitus, biomarker

\section{Introduction}

Diabetes mellitus is one of the most common metabolic disorders characterized by hyperglycemia. ${ }^{1}$ It occurs due to absolute or partial lack of insulin and/or insulin resistance. ${ }^{2}$ Diabetes mellitus is a common public health threat affecting millions of people in the world of all ages, gender, race and ethnic groups. ${ }^{3}$ The burden of DM is increasing throughout the world, and around $80 \%$ of diabetes deaths occur mainly in low and middle-income countries. ${ }^{4}$ Based on the pathogenesis of hyperglycemia, most patients with DM are either Type 1 (insulin dependent) or Type 2 (non-insulin dependent). ${ }^{5}$ Among which, T2DM has been most commonly reported (90-95\% of cases). ${ }^{6}$

According to World Health Organization (WHO) report in 2019, DM affects around 422 million adults in the world. ${ }^{2}$ In 2013, DM was the seventh leading cause of death (causing 74.9 thousand deaths) and it is the eighth leading cause of disability (causing 1.85 million years living with disability). ${ }^{7}$ It is also estimated that diabetes will affect 642 million in $2040 .{ }^{8}$ Even though the prevalence of DM diagnosed patients is high, nearly half of them are unaware of their disease. ${ }^{9}$ On the other hand, according to the International Diabetes Federation, T2DM contributes for the sufferings of about 415 million people in the world; and it is becoming increasing in its prevalence. ${ }^{10}$ 
The pathologic hallmarks of T2DM are mainly abnormal insulin secretion and increased insulin resistance. There is also a decrease in the functional pancreatic $\beta$-cell mass over time upon the progression of the disease condition. ${ }^{11}$ T2DM is associated mainly with obesity, which results in impaired insulin mediated glucose uptake due to intracellular impairment of insulin signaling. There is also a significant reduction in glucagon-like peptide-1 secretion, which is secreted after food ingestion and increases insulin secretion, in patients with T2DM. ${ }^{12}$

If left untreated, DM is associated with devastating shortterm (diabetic ketoacidosis and hyperosmolar hyperglycemic state) and long-term (retinopathy, nephropathy, neuropathy and lower limp amputation) complications. 5,13,14 Moreover, different cardiovascular and endocrine abnormalities are associated with DM, which can affect the quality of life of patients. $^{8,15}$

The diagnosis of DM has been varied from time to time. However, recurrent or persistent hyperglycemia is used to characterize DM. Different diagnostic parameters were used to assess patients with DM including, fasting plasma glucose (FPG), oral glucose tolerance test (OGTT) and Hemoglobin Alc (HgA1c). ${ }^{16,17}$ However, these diagnostic tools are associated with reduced sensitivity and/or specificity to detect diabetes in its early stage. ${ }^{18}$ To overcome such problems different newer diagnostic methods were developed by targeting endogenous proteins such as Leptin, TNF-alpha, C-reactive protein (CRP), ${ }^{19}$ Netrin, $^{20}$ Thioredoxin-interacting protein (TXNIP). ${ }^{3}$ But, these novel methods have been also associated with increased cost. $^{21}$ Hence, the present review is used to assess the role of Adipsin as a novel diagnostic parameter and its implication in T2DM.

\section{Overview of Adipsin}

Adipose tissue is no longer regarded as a passive site for energy accumulation in the form of triacylglycerols. Nevertheless, it is also a vital endocrine gland that secretes many bioactive molecules. ${ }^{22,23}$ Adipokines (or adipocytokines) can be defined as a group of more than 600 bioactive molecules made from adipose tissue that acts as paracrine and endocrine hormones. ${ }^{23,24}$ Adipokines are involved in maintaining varieties of processes such as, appetite and satiety, energy expenditure activity, endothelial function, blood pressure, hemostasis, adipogenesis, insulin sensitivity, energy metabolism in insulin-sensitive tissues, fat distribution and insulin secretion in pancreatic $\beta$-cells. ${ }^{25-27}$ Adipsin, also termed as complement factor $\mathrm{D}$, is one of the adipokines which was the first described adipokine. ${ }^{28}$ Adipsin is a member of the serine protease family with a 28-kilo Dalton protein found in $3 \mathrm{~T} 3$ adipocytes. ${ }^{29}$ Adipsin maintain adipose tissue homeostasis and increases insulin secretion in response to glucose. Additionally, it catalyzes $\mathrm{C} 3 \mathrm{a}$ (an active form of component $3, \mathrm{C} 3$ ) production by controlling the alternative complement pathway causing an increase in insulin secretion from the pancreas. ${ }^{30,31}$

Adipsin is important in the formation of the C5-C9 membrane attack complex and in the generation of various signaling molecules, comprising the anaphylatoxins, complement $3 \mathrm{a}(\mathrm{C} 3 \mathrm{a})$ and $\mathrm{C} 5 \mathrm{a} .{ }^{30}$ In the synthesis, these signaling molecules, first complement factor B is cleaved by Adipsin and these catalyze the formation of C3 convertase and it leads to the hydrolysis cascade that produces different complement fragments including $\mathrm{C} 3 \mathrm{a}, \mathrm{C} 3 \mathrm{~b}, \mathrm{C} 5 \mathrm{a}$ and $\mathrm{C} 5 \mathrm{~b}{ }^{32}$ It was reported that familial $\mathrm{C} 3$ deficiency is associated with obesity and metabolic diseases, and $\mathrm{C} 3$ a levels are risk factors for DM. ${ }^{33}$ The overall effect of Adipsin on insulin secretion is summarized in Figure 1.



Figure I Effect of adipsin on insulin secretion. 
Table I Serum Levels of Adipsin in Type 2 Diabetes Mellitus

\begin{tabular}{|c|c|c|c|}
\hline $\begin{array}{l}\text { Study } \\
\text { Design }\end{array}$ & Method and Intervention & Treatment Outcome & Reference \\
\hline Clinical Study & $\begin{array}{l}37 \text { patients with known T2DM ( } 21 \text { males and } 16 \text { females) } \\
\text { and } 43 \text { controls ( } 28 \text { males and I } 5 \text { females) were taken; and } \\
\text { serum Adipsin was measured using human Adipsin/factor } \\
\text { D ELISA kit with a minimum detectable dose of } 4 \mathrm{pg} / \mathrm{mL} \\
\text { made by RayBiotech, Inc, and glucose level was measured. }\end{array}$ & $\begin{array}{l}\text { Plasma Adipsin levels were lowered and inversely related } \\
\text { with fasting glucose levels in T2DM patients. }\end{array}$ & 34 \\
\hline $\begin{array}{l}\text { Case-Control } \\
\text { Study }\end{array}$ & $\begin{array}{l}\text { Serum Adipsin was measured by using Enzyme- Linked } \\
\text { Immune-sorbent Assay (ELISA Kit) in } 43 \text { patients with } \\
\text { T2DM and } 4 \text { I healthy subjects. }\end{array}$ & $\begin{array}{l}\text { Serum concentrations of Adipsin were reduced in the } \\
\text { patients with T2DM compared to the control group. } \\
\text { Adipsin levels were also inversely related with fasting } \\
\text { glucose levels. }\end{array}$ & 35 \\
\hline Clinical Study & $\begin{array}{l}\text { Serum Adipsin levels were measured in } 240 \text { subjects with } \\
\text { no history of diabetes and } 80 \text { patients with known T2DM } \\
\text { on diet control or metformin monotherapy. }\end{array}$ & $\begin{array}{l}\text { Plasma Adipsin levels were higher in subjects with normal } \\
\text { glucose tolerance or pre-diabetes compared with subjects } \\
\text { with newly diagnosed diabetes or with known T2DM on } \\
\text { diet control or metformin monotherapy. }\end{array}$ & 36 \\
\hline Clinical Study & $\begin{array}{l}\text { Serum Adipsin was evaluated in } 56 \text { patients with newly } \\
\text { diagnosed T2DM, } 36 \text { patients with impaired glucose } \\
\text { tolerance (IGT) and } 45 \text { individuals with normal glucose } \\
\text { tolerance. Pancreatic } \beta \text {-cell function was evaluated using } \\
\text { intravenous glucose tolerance tests. Additionally, serum } \\
\text { levels of interleukin- } I \beta \text { and high sensitivity C reactive } \\
\text { protein were determined. }\end{array}$ & $\begin{array}{l}\text { Serum concentrations of Adipsin were lower in patients } \\
\text { with T2DM and IGT compared to control group. Adipsin } \\
\text { was negatively correlated with waist-to-hip ratio, free fatty } \\
\text { acid, fasting plasma glucose, 2-h postprandial plasma } \\
\text { glucose, glycated hemoglobin, homeostasis model } \\
\text { assessment of insulin resistance, interleukin-I } \beta \text { and high- } \\
\text { sensitivity C-reactive protein. It was positively correlated } \\
\text { with homeostasis model assessment of } \beta \text {-cell function } \\
\text { (HOMA- } \beta \text { ), high-density lipoprotein cholesterol, the area } \\
\text { under the curve of the first phase insulin secretion and } \\
\text { acute insulin response. }\end{array}$ & 29 \\
\hline Clinical Study & $\begin{array}{l}\text { A comprehensive clinical and Laboratory examination was } \\
\text { performed on } 262 \text { subjects ( } 100 \text { men and } 162 \text { women). } \\
\text { Out of these, I55 of them had abdominal obesity, and } 63 \text { of } \\
\text { them had DM. Then, tissue-specific expression of CFD } \\
\text { genes encoding Adipsin were determined. }\end{array}$ & $\begin{array}{l}\text { The expression level of the CFD gene, which encodes } \\
\text { Adipsin, was significantly increased in mesenteric adipose } \\
\text { tissue and subcutaneous adipose tissue in patients with } \\
\text { abdominal obesity. The increased Adipsin production in } \\
\text { adipose tissue in all patients with abdominal obesity and in } \\
\text { obese non-diabetic patients can be regarded as } \\
\text { a compensatory response aimed at normalization of lipid } \\
\text { metabolism. Thus, disturbance of reciprocal relationships } \\
\text { of Adipsin in obesity is associated with the development of } \\
\text { insulin resistance. }\end{array}$ & 37 \\
\hline Clinical Study & $\begin{array}{l}\text { Plasma levels of Adipsin were determined in individuals with } \\
44 \text { pulmonary tuberculosis with diabetes mellitus (PTB- } \\
\text { DM) or } 44 \text { latent tuberculosis with diabetes mellitus (LTB- } \\
\text { DM) and were compared with } 44 \text { pulmonary tuberculosis } \\
\text { (PTB0 or } 44 \text { latent tuberculosis (LTB) without DM. }\end{array}$ & $\begin{array}{l}\text { There was diminished circulating levels of Adipsin in PTB- } \\
\text { DM or LTB-DM individuals. Additionally, Adipsin exhibit } \\
\text { a negative correlation with HbAIC levels and random } \\
\text { blood glucose levels. }\end{array}$ & 38 \\
\hline Cohort Study & $\begin{array}{l}\text { Serum Adipsin levels were determined in a total of } 197 \\
\text { individuals containing of obese men }(n=65) \text { and women ( } n \\
=130 \text { ) who underwent open abdominal surgery for } \\
\text { elective cholecystectomy, sleeve gastrectomy, and Roux-en } \\
-Y \text { bypass surgery. Individuals were categorized in to those } \\
\text { withT2DM ( } n=90) \text { or normal glucose tolerance }(n=97) \\
\text { based on oral glucose tolerance test. Serum Adipsin was } \\
\text { measured by an ELISA. }\end{array}$ & $\begin{array}{l}\text { There was a decrease in serum Adipsin levels in diabetic } \\
\text { patients with } \beta \text {-cell failure. }\end{array}$ & 30 \\
\hline
\end{tabular}


Table I (Continued).

\begin{tabular}{|c|c|c|c|}
\hline $\begin{array}{l}\text { Study } \\
\text { Design }\end{array}$ & Method and Intervention & Treatment Outcome & Reference \\
\hline $\begin{array}{l}\text { Experimental } \\
\text { Study }\end{array}$ & $\begin{array}{l}\text { Wistar albino rats were divided into three groups } \\
\text { containing } 7 \text { rats per group: control group receiving food } \\
\text { and water, diabetic group taking metformin } 200 \mathrm{mg} / \mathrm{kg} / \mathrm{day} \text {, } \\
\text { and diabetic control group taking food and water. All } \\
\text { treatments were given for } 6 \text { weeks. Then, circulating levels } \\
\text { of plasma Adipsin were measured by using specific ELISA } \\
\text { kits, and insulin resistance was evaluated. }\end{array}$ & $\begin{array}{l}\text { Circulating concentrations of Adipsin were significantly } \\
\text { reduced in diabetic rats. There was a negative correlation } \\
\text { between plasma Adipsin levels and insulin resistance. }\end{array}$ & 39 \\
\hline $\begin{array}{l}\text { Cross- } \\
\text { Sectional } \\
\text { Study }\end{array}$ & $\begin{array}{l}\text { Serum levels of Adipsin were evaluated in a total of I } 25 \\
\text { T2DM patients, including } 82 \text { subjects with obesity. } 30 \\
\text { healthy individuals, matched by sex and age, were } \\
\text { considered as control. Concentrations of Adipsin in fasting } \\
\text { serum were determined using multiplex analysis. }\end{array}$ & $\begin{array}{l}\text { Patients with diabetes had significantly higher levels of } \\
\text { Adipsin compared to the control group. }\end{array}$ & 40 \\
\hline $\begin{array}{l}\text { Risk-Score } \\
\text { Approach }\end{array}$ & $\begin{array}{l}\text { Plasma concentrations of Adipsin was using commercially } \\
\text { available ELISA kits determined in a total of I } 30 \text { individuals } \\
\text { with T2DM and I6I individuals without T2DM. }\end{array}$ & $\begin{array}{l}\text { Higher levels of Adipsin were observed in subjects with } \\
\text { T2DM. }\end{array}$ & 41 \\
\hline Cohort Study & $\begin{array}{l}\text { A total of } 6886 \text { individuals were studied who were } \\
\text { attending Offspring Exam } 8 \text { and Third Generation Exam } 2 \\
\text { examinations. Plasma Adipsin was assayed using a modified } \\
\text { ELISA sandwich approach. Fasting glucose and insulin } \\
\text { concentrations were assayed using fasting plasma Linco } \\
\text { insulin (Offspring) and a Linco human insulin ELISA kit } \\
\text { (Third Generation). Insulin resistance was determined } \\
\text { using the homeostatic model assessment for insulin } \\
\text { resistance (HOMA-IR). }\end{array}$ & $\begin{array}{l}\text { Higher levels of Adipsin were associated with lower fasting } \\
\text { glucose levels and with a trend toward improved insulin } \\
\text { resistance. }\end{array}$ & 31 \\
\hline $\begin{array}{l}\text { Observational } \\
\text { Study }\end{array}$ & $\begin{array}{l}363 \text { obese and } 365 \text { non-obese individuals were evaluated } \\
\text { for Adipsin, body mass index, fasting plasma glucose, fasting } \\
\text { plasma insulin, homeostasis model assessment index. }\end{array}$ & $\begin{array}{l}\text { Higher Adipsin level, BMI, fasting plasma insulin, } \\
\text { homeostasis model assessment index was observed in } \\
\text { obese subjects. }\end{array}$ & 42 \\
\hline
\end{tabular}

Abbreviations: T2DM, type 2 diabetes mellitus; ELISA, enzyme-linked immune-sorbent assay; DM, diabetes mellitus; PTB-DM, pulmonary tuberculosis with diabetes mellitus; LTB-DM, latent tuberculosis with diabetes mellitus; IGT, impaired glucose tolerance; HbAIC, hemoglobin AIC; CFD, complement factor D; HOMA- $\beta$, homeostasis model assessment of $\beta$-cell function; HOMA-IR, homeostatic model assessment for insulin resistance.

\section{Preclinical and Clinical Studies on the Serum Levels of Adipsin in Type 2 Diabetes Mellitus}

Circulating Adipsin levels are negatively correlated with T2DM. Various experimental and clinical studies showed that plasma concentrations of Adipsin is decreased in humans and animals with DM compared to the normal control group as indicated in the table below (Table 1).

\section{Implications of Adipsin in Type 2 Diabetes Mellitus}

Type 2 diabetes mellitus is characterized by an increase in blood glucose level caused by pancreatic $\beta$-cell failure and/or insulin resistance. ${ }^{43}$ Adipsin is reported to maintain $\beta$-cell function, which is important to boost insulin secretion. ${ }^{30}$ According to a study by Gómez-Banoy et $\mathrm{al}^{31}$, restoration of Adipsin in diabetic mice did not merely improve hyperglycemia, rather it also preserves $\beta$-cell mass by improving $\beta$-cell survival and maintaining $\beta$-cell transcriptional identity. Additionally, increased Adipsin level is associated with lower risk of diabetes in humans. ${ }^{31}$

Patients with newly diagnosed diabetes and known T2DM show a decreased levels of Adipsin; and there is an independent negative association between Adipsin and HOMA-IR. It was concluded that the negative association might be due to the expression of inflammatory cytokines like IL-17 in T2DM. ${ }^{36}$ The plasma concentrations of Adipsin were reduced in T2DM patients with impaired glucose tolerance; which is associated with the first-phase 
insulin secretion of pancreatic $\beta$-cells and glucose metabolism. This was evidenced by the positive correlation between serum Adipsin and HOMA- $\beta .^{29}$

In obesity complicated with T2DM, there is a disturbance in the relationship between Adipsin and leptin. An increase in Adipsin production in obesity can be regarded as a compensatory response for normalizing the parameters of the lipid and carbohydrate metabolism. ${ }^{37}$

Unlike other insulin secretagogues, various preclinical studies showed that Adipsin replenishment in diabetic mice reduces hyperglycemia, and raises insulin levels while maintaining $\beta$-cells by stopping dedifferentiation and death. In recent times, Adipsin has been found capable of promoting insulin secretion and stabilizing plasma glucose levels. In addition, diabetic mice treated with Adipsin showed significant reductions in fasting plasma glucose and increased glucose clearance, while fasting and glucose-induced insulin levels were also improved. ${ }^{27,30}$ Adipsin could also stimulate glucose transport for triglyceride accumulation in adipose tissue and inhibits lipolysis. It is justified that free fatty acids could exacerbate pancreatic $\beta$-cell failure and insulin resistance. ${ }^{37}$

On the other hand, the negative correlation between Adipsin and insulin resistance in diabetic rats implies that Adipsin might increase insulin sensitivity and reduce glucose intolerance in T2DM. ${ }^{39}$ As explained by Lo et al, the possible mechanism by which Adipsin increases insulin secretion is via generating $\mathrm{C} 3 \mathrm{a}$. $\mathrm{C} 3 \mathrm{a}$ acts on islets of the pancreas by augmenting its receptor $(\mathrm{C} 3 \mathrm{aR} 1)$ and inhibiting ATP sensitive $\mathrm{K}^{+}$ channel, thus, increasing intracellular $\mathrm{Ca}^{2+}$ concentrations. ${ }^{30}$

Klimontov et $\mathrm{al}^{40}$ reported that the serum concentrations of Adipsin were increased in patients with T2DM by which they did not confirm the inverse relationship of Adipsin with T2DM. The possible reasons for these inconsistencies could be that the authors used small sample size of patients, a large number of patients receiving insulin therapy, and unable to differentiate subcutaneous and visceral fat depots as stated in their paper as a limitation of their study.

\section{Conclusion and Future Perspective}

Though there are different diagnostic and management modalities for DM, it is becoming a public health threat causing different micro and macro-complications in the world. To prevent these complications and to reduce mortality associated with DM, searching new promising diagnostic and therapeutic options are important. Adipsin, secreted by the adipocytes, has a crucial role in maintaining adipose tissue homeostasis and increases insulin secretion in response to glucose. It has the potential to become an early novel biomarker in patients with T2DM.

Various clinical and animal studies showed that there is a reduction in the plasma concentrations of Adipsin in animals/humans with DM. Additionally, Adipsin has varieties of effects in the pancreas including preserving $\beta$-cell mass by improving $\beta$-cell survival and maintaining $\beta$-cell transcriptional identity, and promoting insulin secretion from the $\beta$ cells of the pancreas. It also stimulates glucose transport for triglyceride accumulation in adipose tissue and inhibits lipolysis.

Further detailed animal and human studies will be required to confirm Adipsin as a novel biomarker for T2DM. Additionally, further investigations are in need to decide the mechanism by which Adipsin increases insulin secretion from $\beta$-cells of the pancreas. Adipsin has a biological function in in vivo studies and could be considered as a therapeutic option in the future.

\section{Abbreviations}

ADA, American Diabetes Association; CFD, complement factor D; CRP, C-reactive Protein; DM, diabetes mellitus; ELISA, enzyme linked immune-sorbent assay; FPG, fast plasma glucose; HgA1C, hemoglobin A1C; HOMA-IR, homeostasis model assessment-insulin resistance; IGT, impaired glucose tolerance; LTB, latent tuberculosis; OGTT, Oral Glucose Tolerance Test; PLB, pulmonary tuberculosis; T2DM, type 2 diabetes mellitus; TNF, tumor necrosis factor; TXNIP, thioredoxin interacting protein; WHO, World Health Organization.

\section{Author Contributions}

All authors contributed to data analysis, drafting or revising the article, gave final approval of the version to be published, and agree to be accountable for all aspects of the work.

\section{Disclosure}

The authors report no conflicts of interest in this work.

\section{References}

1. Oguntibeju O. Pathophysiology and Complications of Diabetes Mellitus. BoD-Books on Demand; 2012.

2. WHO. Classification of Diabetes Mellitus. World Health Organization; 2019:1-40. Licence: CC BY-NC-SA 3.0 IGO 2019.

3. Wondafrash DZ, Nire'a AT, Tafere GG, Desta DM, Berhe DA, Zewdie KA. Thioredoxin-interacting protein as a novel potential therapeutic target in diabetes mellitus and its underlying complications. Diabetes Metab Syndr Obes. 2020;13:43. doi:10.2147/DMSO. S232221 
4. Afroz A, Ali L, Karim MN, et al. Glycaemic control for people with type 2 diabetes mellitus in Bangladesh-an urgent need for optimization of management plan. Sci Rep. 2019;9(1):1-10. doi:10.1038/ s41598-019-46766-9

5. Baynes HW. Classification, pathophysiology, diagnosis and management of diabetes mellitus. J Diabetes Metab. 2015;6(5):1-9.

6. ADA. Diagnosis and classification of diabetes mellitus. Diabetes Care. 2014;37(Supplement 1):S81-S90. doi:10.2337/dc14-S081

7. Asmelash D, Asmelash Y. The burden of undiagnosed diabetes mellitus in adult African population: a systematic review and meta-analysis. J Diabetes Res. 2019;2019:1-8. doi:10.1155/2019/4134937

8. Fan W. Epidemiology in diabetes mellitus and cardiovascular disease. Cardiovasc Endocrinol. 2017;6(1):8-16. doi:10.1097/XCE.0000000 000000116

9. Piero M, Nzaro G, Njagi J. Diabetes mellitus-a devastating metabolic disorder. Asian J Biomed Pharm Sci. 2015;5(40):1.

10. Elekofehinti OO, Ejelonu OC, Kamdem JP, Akinlosotu OB, Adanlawo IG. Saponins as adipokines modulator: a possible therapeutic intervention for type 2 diabetes. World J Diabetes. 2017;8 (7):337. doi:10.4239/wjd.v8.i7.337

11. Kohei K. Pathophysiology of type 2 diabetes and its treatment policy. Jpn Med Assoc J. 2010;53(1):41-46.

12. Zaccardi F, Webb DR, Yates T, Davies MJ. Pathophysiology of type 1 and type 2 diabetes mellitus: a 90-year perspective. Postgrad Med J. 2016;92(1084):63-69. doi:10.1136/postgradmedj-2015-133281

13. Heng L, Comyn O, Peto T, et al. Diabetic retinopathy: pathogenesis, clinical grading, management and future developments. Diabet Med. 2013;30(6):640-650. doi:10.1111/dme.12089

14. Wang W, Lo AC. Diabetic retinopathy: pathophysiology and treatments. Int J Mol Sci. 2018;19(6):1-14.

15. Skyler JS, Bakris GL, Bonifacio E, et al. Differentiation of diabetes by pathophysiology, natural history, and prognosis. Diabetes. 2017;66(2):241-255. doi:10.2337/db16-0806

16. Lyons TJ, Basu A. Biomarkers in diabetes: hemoglobin A1c, vascular and tissue markers. Transl Res. 2012;159(4):303-312. doi:10.1016/j. trs1.2012.01.009

17. Diwaker A, Kishore D, Singh V, Mahapatra SP. The novel biomarkers in diabetes. J Assoc Physicians India. 2019;67(7):65-69.

18. Punthakee Z, Goldenberg R, Katz P. Définition, classification et diagnostic du diabète, du prédiabète et du syndrome métabolique. Can J Diabetes. 2018;42:S10-S15. doi:10.1016/j.jcjd.2017.10.003

19. Riaz S. Study of protein biomarkers of diabetes mellitus type 2 and therapy with vitamin B1. J Diabetes Res. 2015;2015:1-10. doi:10.1155/2015/150176

20. Yimer EM, Zewdie KA, Hishe HZ. Netrin as a novel biomarker and its therapeutic implications in diabetes mellitus and diabetes-associated complications. J Diabetes Res. 2018;2018:1-20. doi:10.1155/2018/ 8250521

21. Laakso M. Biomarkers for type 2 diabetes. Mol Metab. 2019;27: S139-S146. doi:10.1016/j.molmet.2019.06.016

22. Lu B, Zhao M, Jiang W, et al. Independent association of circulating level of chemerin with functional and early morphological vascular changes in newly diagnosed type 2 diabetic patients. Medicine. 2015;94(47):1-8. doi:10.1097/MD.0000000000001990

23. Mamdouh M, Shaban S, Ibrahim Abushouk A, Zaki MMM, Ahmed OM, Abdel-Daim MM. Adipokines: potential therapeutic targets for vascular dysfunction in type II diabetes mellitus and obesity. J Diabetes Res. 2017;2017:1-11.

24. Blüher M. Adipokines-removing road blocks to obesity and diabetes therapy. Mol Metab. 2014;3(3):230-240. doi:10.1016/j.molmet. 2014.01.005

25. Tilg H, Moschen AR. Adipocytokines: mediators linking adipose tissue, inflammation and immunity. Nat Rev Immunol. 2006;6 (10):772-783. doi:10.1038/nri1937
26. Blüher M. Clinical relevance of adipokines. Diabetes Metab J. 2012;36(5):317-327. doi:10.4093/dmj.2012.36.5.317

27. Freitas Lima LC, Braga V, Do Socorro de França Silva M, et al. Adipokines, diabetes and atherosclerosis: an inflammatory association. Front Physiol. 2015;6:304. doi:10.3389/fphys.2015.00304

28. Cook KS, Groves DL, Min HY, Spiegelman BM. A developmentally regulated mRNA from $3 \mathrm{~T} 3$ adipocytes encodes a novel serine protease homologue. Proc Natl Acad Sci. 1985;82(19):6480-6484. doi:10.1073/pnas.82.19.6480

29. Zhou Q, Ge Q, Ding Y, et al. Relationship between serum adipsin and the first phase of glucose-stimulated insulin secretion in individuals with different glucose tolerance. $J$ Diabetes Investig. 2018;9 (5):1128-1134. doi:10.1111/jdi.12819

30. Lo JC, Ljubicic S, Leibiger B, et al. Adipsin is an adipokine that improves $\beta$ cell function in diabetes. Cell. 2014;158(1):41-53. doi:10.1016/j.cell.2014.06.005

31. Gómez-Banoy N, Guseh JS, Li G, et al. Adipsin preserves beta cells in diabetic mice and associates with protection from type 2 diabetes in humans. Nat Med. 2019;25(11):1739-1747. doi:10.1038/s41591019-0610-4

32. Baas T. Adipsin meets $\beta$ cells. Sci Bus Exch. 2014;7(30):883-886. doi:10.1038/scibx.2014.883

33. Song N-J, Kim S, Jang B-H, et al. Small molecule-induced complement factor D (Adipsin) promotes lipid accumulation and adipocyte differentiation. PLoS One. 2016;11(9):e0162228. doi:10.1371/journal.pone. 0162228

34. Legakis I, Mantzouridis T, Bouboulis G, Chrousos GP. Reciprocal changes of serum adispin and visfatin levels in patients with type 2 diabetes after an overnight fast. Arch Endocrinol Metab. 2016;60 (1):76-78. doi:10.1590/2359-3997000000147

35. Karajibani M, Montazerifar F, Sadeghi MB, Keikhaie MA, Dashipour A. Serum fetuin-A and adipsin levels in type II diabetes patients. Int J High Risk Behav Addict. 2019;1-6.

36. Wang J-S, Lee W-J, Lee I-T, et al. Association between serum Adipsin levels and insulin resistance in subjects with various degrees of glucose intolerance. $J$ Endocr Soc. 2019;3(2):403-410. doi:10.1210/js.2018-00359

37. Vasilenko MA, Kirienkova EV, Skuratovskaia DA, et al., editors. The role of production of adipsin and leptin in the development of insulin resistance in patients with abdominal obesity. Dokl Biochem Biophys. 2017;475:271-276. doi:10.1134/S160767291704010X

38. Kumar NP, Nair D, Banurekha V, et al. Type 2 diabetes mellitus coincident with pulmonary or latent tuberculosis results in modulation of adipocytokines. Cytokine. 2016;79:74-81. doi:10.1016/j. cyto.2015.12.026

39. Taşdemir E, Şermet A. The relationship between plasma adipsin, adiponectin, vaspin, visfatin, and leptin levels with glucose metabolism and diabetes parameters. Haydarpasa Numune Med J. 2019;59 (2):95-103.

40. Klimontov VV, Bulumbaeva DM, Bgatova NP, et al. Serum adipokine concentrations in patients with type 2 diabetes: the relationships with distribution, hypertrophy and vascularization of subcutaneous adipose tissue. Diabetes mellitus. 2019;22(4):336-347. doi:10.14341/ DM10129

41. Cox AJ, Zhang P, Bowden DW, et al. Enteroendocrine and adipokine associations with type 2 diabetes: phenotypic risk scoring approaches. J Gastroenterol Hepatol. 2018;33(7):1357-1364. doi:10.1111/jgh.14057

42. Derosa G, Fogari E, D'Angelo A, et al. Adipocytokine levels in obese and non-obese subjects: an observational study. Inflammation. 2013;36(4):914-920. doi:10.1007/s10753-013-9620-4

43. Azizi M, Tadibi V, Behpour N. The effect of aerobic exercise training on $\beta$-cell function and circulating levels of adipsin in community of obese women with type 2 diabetes mellitus. Int $J$ Diabetes Dev Ctries. 2017;37(3):298-304. doi:10.1007/s13410-016-0504-7 


\section{Publish your work in this journal}

Diabetes, Metabolic Syndrome and Obesity: Targets and Therapy is an international, peer-reviewed open-access journal committed to the rapid publication of the latest laboratory and clinical findings in the fields of diabetes, metabolic syndrome and obesity research. Origina research, review, case reports, hypothesis formation, expert opinion and commentaries are all considered for publication. The manuscript management system is completely online and includes a very quick and fair peer-review system, which is all easy to use. Visit http://www.dovepress.com/testimonials.php to read real quotes from published authors. 